DOI: $10.19195 / 0137-1134.109 .11$

\title{
POLITYKA ADMINISTRACYJNA A SAMORZĄDOWA POLITYKA OŚWIATOWA — NA GRUNCIE NAUK PRAWNOADMINISTRACYJNYCH*
}

\section{W KIERUNKU ZADAŃ OŚWIATOWYCH JEDNOSTEK SAMORZĄDU TERYTORIALNEGO}

Dla przedstawienia zagadnienia objętego tematem rozważań konieczne jest wyjaśnienie, jak należy rozumieć określenie ,polityka administracyjna”, by następnie odnieść je do podstawowych instrumentów kształtowania polityki oświatowej, a zwłaszcza jej zasięgu lokalnego samorządów, którą należy uznać za część polityki administracyjnej. Wymienione pojęcia dotyczą dwóch zagadnień, które cieszą się aktualnie zainteresowaniem polskiego piśmiennictwa i praktyki administracyjnej ze względu na kształt nowego ustroju szkolnego w ramach reformy oświaty, harmonogramu wdrażania zmian reformy i płynności przepisów prawa oświatowego ${ }^{1}$. Powstaje pytanie, czemu służy i jaki jest wpływ polityki oświatowej na zadania oświatowe jednostek samorządu terytorialnego (dalej: j.s.t.)? Należy przyjąć, że polityka oświatowa samorządu terytorialnego jest pewną strategią nakreślającą główne kierunki rozwoju oświaty lokalnej, długofalowym planem działania na rzecz rozwoju wszystkich obszarów lokalnej edukacji, który pozwala kreować oświatową rzeczywistość przy uwzględnieniu analizy demografii, potrzeb i możliwości j.s.t. oraz oczekiwań jej mieszkańców².

* Stan prawny publikacji na dzień 7 lutego $2017 \mathrm{r}$.

1 Zgodnie z art. 189 ustawy z dnia 14 grudnia 2016 r. Prawo oświatowe (Dz.U. 2017 poz. 59), dalej: p.o. „Ustawa wchodzi w życie w terminie i na zasadach określonych w ustawie z dnia 14 grudnia 2016 r. - Przepisy wprowadzające ustawę — Prawo oświatowe (Dz.U. 2017 poz. 60)”, dalej: u.p.w.p.o.; zob. O reformie, http://reformaedukacji.men.gov.pl/ (dostęp: 15.01.2017). Należy podkreślić, że ustawa z dnia 14 grudnia 2016 r. Prawo oświatowe całkowicie zmienia dotychczas istniejącą strukturę szkolnictwa w Polsce określoną przepisami ustawy z dnia 7 września 1991 r. o systemie oświaty. W tym celu przyjęto ustawę z dnia 14 grudnia 2016 r. — Przepisy wprowadzające ustawę Prawo oświatowe, która określa zasady i mechanizmy wdrożenia Prawa oświatowego.

2 Zob. Jak samorzad może wspierać szkoły? Informacje o nowym systemie wspomagania pracy szkót, red. J. Soćko, A. Gocłowska, Warszawa 2015, s. 46. 
Celem rozważań jest wskazanie na edukację lokalną jako zadanie publiczne w kontekście przejęcia odpowiedzialności państwa i samorządu terytorialnego za jego realizację. Zasadnicze znaczenie mają tu współczesne uwarunkowania administracji publicznej i ich wpływ na politykę oświatową oraz warunki realizacji publicznych zadań oświatowych. Oświata jako zadanie publiczne ${ }^{3} \mathrm{w}$ państwie służy realizacji dobra wspólnego, co ma związek z jej publicznym charakterem, wynikającego z Konstytucji RP i ustawy o systemie oświaty ${ }^{4}$, będącego determinantą zasadniczych celów publicznych i funkcji państwa ${ }^{5}$. Jest ona wspólną wartością ogólnonarodową, co wiąże się z konstytucyjnym prawem do nauki (art. 70 Konstytucji RP) ${ }^{6}$ i z ustawą o systemie oświaty ${ }^{7}$. Wskazuje ona względem tej sfery działania administracji publicznej na jej doniosły charakter jako jednej z podstawowych potrzeb rozwoju społecznego, lecz także koresponduje z odpowiedzialnością państwa i samorządu terytorialnego za funkcjonowanie całego systemu oświaty, której szczególnym przejawem jest wymaganie zapewnienia powszechnej dostępności szkół publicznych ${ }^{8}$.

W doktrynie i orzecznictwie TK przyjmuje się, że

zakwalifikowanie zadań z zakresu edukacji do zadań publicznych ma swoje źródło bezpośrednio w art. 70 Konstytucji RP. Przepis ten statuuje prawo do nauki, nie tylko poprzez jego ustanowienie (ust. 1), ale również wskazanie podstawowych gwarancji jego realizacji, do których zaliczyć trzeba przede wszystkim: wolność wyboru rodzaju szkoły (ust. 3 zd. 1), wolność zakładania szkół różnych typów (ust. 3 zd. 2-3), a także określenie pewnych elementów ustroju szkolnictwa, takich jak: zasada bezpłatności nauki w szkołach publicznych (ust. 2), zasada powszechnego i równego dostępu obywateli do wykształcenia (ust. 4 zd. 1), zasada pomocy władz publicznych dla uczniów i studentów (ust. 4 zd. 2), zasada trójszczeblowości ustroju szkolnictwa (ust. 3 zd. 2), zasada dwusektorowości szkolnictwa, mającego przybierać postać szkolnictwa publicznego i niepublicznego (ust. 3) oraz zasada autonomii szkół wyższych (ust. 5) .

${ }^{3}$ Zob. R. Raszewska-Skałecka, Zadania oświatowe jednostek samorzadu terytorialnego, [w:] Studia nad samorzadem terytorialnym, red. A. Błaś, Wrocław 2002, s. 233-265; P. Chmielnicki, Świadczenie ushug przez samorzad terytorialny w Polsce. Zagadnienia ustrojowoprawne, Warszawa 2005, s. 38; D. Kurzyna-Chmiel, Oświata jako zdanie publiczne, Warszawa 2013; E. Pierzchała, J. Pierzchała, Oświata w sferze ustug publicznych, [w:] Administracja dóbr i usług publicznych, red. M. Woźniak, Warszawa 2013, s. $111 \mathrm{n}$.

${ }^{4}$ Ustawa z dnia 7 września 1997 r. o systemie oświaty (tekst jedn. Dz.U. 2016 poz. 1943 z późn. zm.), dalej: u.s.o.

5 Zob. M. Stahl, Cele publiczne i zadania publiczne, [w:] Koncepcja systemu prawa administracyjnego, red. J. Zimmermann, Warszawa 2007, s. 95 n.

6 Art. 70 Konstytucji Rzeczypospolitej Polskiej z dnia 2 kwietnia 1997 r. (Dz.U. 1997 Nr 78, poz. 483 ze zm.).

7 Oświata stanowi „wspólne dobro całego społeczeństwa”, zaś cele i zadania systemu oświaty określone zostały w art. 1 i 2 u.s.o.

8 Zob. M. Pilich, Ustawa o systemie oświaty. Komentarz, Warszawa 2012, s. 25-26.

9 Por. wyrok TK z dnia 18 grudnia 2008 r., K19/07, OTK ZU 2008/10/A/182. 


\section{W zakresie treści prawa do nauki wskazuje się na}

możliwość zdobywania wiedzy, kształcenia prowadzonego w zorganizowanych formach, w sposób regularny i ciągły, obejmującego najpierw pewien kanon podstawowy wiadomości ogólnych, a następnie umożliwiającego uzyskiwanie pogłębionej wiedzy specjalistycznej, kończonego uzyskaniem dokumentów, jednolicie w skali kraju dających szanse kontynuowania nauki bądź wykonywania określonego zawodu ${ }^{10}$.

W orzecznictwie TK w wyroku z 8 listopada 2000 r., sygn. SK 18/99 zauważa się, że prawo do nauki musi być postrzegane zarówno w kategoriach dobra i wartości indywidualnej, jak i ważnego, podstawowego dobra społecznego. Urzeczywistnienie tego prawa jest nie tyle jakimś szczególnym przywilejem współczesnego człowieka, ile stanowi nieodzowny warunek rozwoju społeczeństwa i jednocześnie pełnego uczestnictwa jednostki w życiu społecznym. Z treści art. 70 Konstytucji RP, jak zauważa TK w wyroku z 16 stycznia 2007 r., sygn. U 5/06 ${ }^{11}$, wynikają w istocie dwie grupy norm, z czego pierwsza ustanawia zadania państwa w zakresie oświaty i nauki, których realizacja stanowi podstawę instytucjonalną dla podmiotowego prawa do nauki oraz druga grupa norm — prawo do nauki. Podmiotowym prawem konstytucyjnym jest powszechny i równy dostęp do wykształcenia jako konieczne elementy prawa do nauki (art. 70 ust. 4 Konstytucji RP) ${ }^{12}$. Takie ujęcie

zobowiązuje władze publiczne do zapewnienia obywatelom równości w dostępie i powszechności kształcenia. Działania podejmowane w tym celu powinny zmierzać przede wszystkim do eliminacji nierówności i barier faktycznych, w tym finansowych. Celem i istotą tego prawa jest stworzenie bowiem jednostce realnych szans kształcenia na różnych poziomach edukacyjnych. [...] powszechność i równość kształcenia rozumiana musi być jako równość szans. Zasady te [...] odnoszą się do kształcenia w szkołach publicznych ${ }^{13}$.

W ocenie TK dbałość o powszechną edukację, a w szczególności sprawne i efektywne prowadzenie polityki oświatowej oraz finansowanie oświaty zaliczyć należy do obowiązków władzy publicznej ${ }^{14}$. Istotnym elementem konstytucyjnego prawa do nauki pozostaje zasada bezpłatności nauczania w szkołach publicznych (art. 70 ust. 2 Konstytucji RP). Z kognicji TK wynika, że

nie istnieje możliwość stworzenia jakiegokolwiek systemu edukacyjnego bez niezbędnych zasobów finansowych, co odnosi się do wszystkich typów szkół i wszystkich poziomów i rodzajów kształcenia, zatem nieodpłatność może być jedynie rozumiana jako pewna określona formuła finansowania kształcenia z zasobów publicznych. Związanie zasady bezpłatnego nauczania z funkcją szkół publicznych jest wyrazem koncepcji realizacji przez władzę publiczną zadań określonych przez samą

${ }^{10}$ L. Garlicki, Komentarz do art. 70, [w:] Konstytucja Rzeczypospolitej Polskiej. Komentarz, red. L. Garlicki, t. 3, Warszawa 2003, s. 3.

11 OTK ZU nr 1/A/2007, poz. 3.

12 Zob. L. Garlicki, Uwagi do art. 70, [w:] Konstytucja Rzeczypospolitej..., s. 3.

13 Wyrok TK z dnia 9 czerwca 2010 r., sygn. K 29/7, OTK ZU z 2010 r., seria A, Nr 5, poz. 49; wyrok TK z dnia 24 września 2013 r., sygn. K 35/12, OTK ZU nr 7/A/2013, poz. 94.

14 Postanowienie TK z dnia 6 listopada 2012 r., sygn. akt K 5/12, OTK ZU nr 10/A/2012, poz. 125 . 
Konstytucję, związanych z kształtowaniem systemu edukacji opartego na równym i powszechnym dostępie do edukacji15.

W zakresie wykonywania obowiązku szkolnego Konstytucja RP odsyła do uszczegółowienia treści prawa do nauki do ustawy o systemie oświaty ${ }^{16}$.

Należy podkreślić, że w wyniku reformy samorządowej z 1999 r. państwo scedowało praktycznie całkowicie obowiązek prowadzenia szkół na j.s.t. ${ }^{17}$ Znaczącą rolę w ustaleniu zakresu pojęcia i sposobu realizacji zadań publicznych ma kreowana w danym okresie polityka edukacyjna państwa, która wywiera wpływ na zmieniające się zadania, cele, a szerzej — interes publiczny, przeobrażenia oświaty i sposoby jej organizacji czy zarządzania, a także prawo, mające być ostoją polityki oświatowej i gwarantujące sposób zaspokajania potrzeb oświatowych, działania administracji publicznej prowadzące do czynienia z oświaty dobra o charakterze powszechnie dostępnym i obowiązku prawnym realizacji publicznych zadań oświatowych ${ }^{18}$. Nie ulega wątpliwości, że trwałość zaspokajania potrzeb w zakresie edukacji jest zapewniana przez nałożenie odpowiedzialności za realizację przedmiotowego zadania publicznego na administrację publiczną. Zauważmy, że w nauce prawa administracyjnego S. Fundowicz, jako punktu wyjścia przy określeniu zadania publicznego, sięgnął do pojęcia administracji publicznej według J. Bocia ${ }^{19}$. Sławomir Fundowicz definiuje zadanie publiczne jako „przejęte przez państwo zaspokajanie zbiorowych i indywidualnych potrzeb człowieka, wynikających ze współżycia ludzi w społecznościach" ${ }^{20}$. W zdefiniowaniu tego pojęcia autor wyróżnia dwa elementy: materialny i formalny. W pierwszym, jak wskazuje, chodzi o zaspokajanie zbiorowych i indywidualnych potrzeb człowieka, wynikających ze współżycia ludzi w społeczności. Za aspektem tym, jak twierdzi, podąża aspekt formalny, polegający na tym, że państwo przejmuje zaspokajanie wcześniej ustalonych potrzeb. Kontynuując tę myśl, S. Fundowicz stwierdza:

15 OTK ZU nr 5/A/2010, poz. 49.

16 Ibidem.

17 Wyrok NSA w Warszawie z dnia 28 stycznia 2014 r., I OSK 2076/13. Szkoły niepubliczne jako podmioty wykonujące zadania publiczne w rozumieniu art. 4 ust. 1 pkt 5 u.d.i.p.

18 Zob. D. Kurzyna-Chmiel, op. cit., s. 16; R. Raszewska-Skałecka, Między tradycja a przyszłościa w polskim systemie edukacji — wyrównywanie szans edukacyjnych, [w:] Między tradycja a przyszłościa w nauce prawa administracyjnego. Ksiegga jubileuszowa dedykowana Profesorowi Janowi Bociowi, red. J. Supernat, Wrocław 2009, s. 593 n.; eadem, Decentralizacja zadań oświatowych w kontekście wyzwań i oczekiwań spotecznych, [w:] Administracja publiczna wobec wyzwań i oczekiwań społecznych, red. M. Giełda, R. Raszewska-Skałecka, Wrocław 2015, s. 145-164.

19 Prawo administracyjne, red. J. Boć, Wrocław 2004, s. 16. Jan Boć definiuje administrację publiczną jako ,przejęte przez państwo i realizowane przez jego zawisłe organy, a także organy samorządu terytorialnego zaspokajanie zbiorowych $\mathrm{i}$ indywidualnych potrzeb obywateli wynikających ze współżycia ludzi w społecznościach”, zwracając uwagę na trzy pojęcia: państwo (lub samorząd terytorialny), obywateli, społeczność.

20 S. Fundowicz, Dynamiczne rozumienie zadania publicznego, [w:] Między tradycją a przyszłością..., s. 158. 
Przejęcie przez państwo dokonuje się przez ustalenie w normie prawnej pewnych działań jako zadań publicznych albo przez powszechne przypisywanie pewnych działań do zakresu zadań publicznych w ramach obrotu prawnego, albo też na podstawie bezspornego, niebudzącego wątpliwości domniemania, że określone działanie jest wykonywaniem zadania publicznego, zwłaszcza gdy działania tego podejmuje się osoba prawna prawa publicznego, a działanie to nie zostało dookreślone w normie prawnej jako czynność prawna prawa prywatnego ${ }^{21}$.

Jeśli cała działalność administracji publicznej polega na wykonywaniu zadań publicznych, to zaspokajanie potrzeb w dziedzinie edukacji (potrzeby wiedzy) stanowi ze strony administracji publicznej świadczenie usług ${ }^{22}$. Odpowiedzialność państwa za kierunki rozwoju polityki oświatowej i warunki realizacji publicznych zadań oświatowych należy odnieść do jednostek samorządu terytorialnego, o których mowa w ustawie o systemie oświaty (m.in. art. 3 pkt 5, art. 3 pkt 14, art. 5 ust. 2 pkt 1 i ust. 3 u.s.o.) - jako zdecentralizowanych podmiotów władzy publicznej.

Wszystkie zadania wykonywane przez j.s.t. mają charakter zadań publicznych $^{23}$. Ma to również odzwierciedlenie w uchwale TK z dnia 27 września 1994 r., zgodnie z którą ,wszystkie zadania samorządu terytorialnego mają charakter zadań publicznych $\mathrm{w}$ tym znaczeniu, że służą zaspokojeniu potrzeb zbiorowych społeczności czy to lokalnych, w wypadku zadań własnych, czy zorganizowanego w państwo całego społeczeństwa, jak w wypadku zadań zleconych"24. Jak zauważa TK,

wykonywane przez samorząd terytorialny zadania mają charakter funkcji państwa rozumianego jako powszechna organizacja władzy publicznej i dlatego powinny podlegać rygorom przewidzianym przez konstytucję dla wykonywania funkcji państwowych. Muszą w szczególności pozostawać w zgodności z fundamentalną zasadą demokratycznego państwa prawnego, co oznacza, że realizując swoje zadania, działać powinny nie tylko »w ramach ustaw «, lecz ponadto — zgodnie z elementarną zasadą legalizmu uzupełniającą i konkretyzującą zasadę demokratycznego państwa prawnego, »na podstawie przepisów prawa«, zaś przestrzeganie praw Rzeczypospolitej Polskiej jest ich podstawowym obowiązkiem tak samo jak każdego organu państwa. Nie do przyjęcia byłby pogląd, że w demokratycznym państwie prawnym zadania publiczne, stanowiące formę realizacji władztwa państwowego, a zatem odnoszące się do stosunków między instytucjami władzy i obywatelami, podlegają w różnym stopniu rygorom praworządności i legalności, w zależności od charakteru prawnego podmiotu mającego kompetencję do ich wykonywania ${ }^{25}$.

\section{W literaturze prawniczej przyjmuje się, że}

Samorząd terytorialny wykonuje zadania publiczne w imieniu własnym i na własną odpowiedzialność. Jednostka samorządu terytorialnego jako element administracji publicznej nie działa

\section{Ibidem}

22 Zob. P. Chmielnicki, op. cit., s. 38. Świadczenie usług przez administrację, zdaniem autora, „to istotna część funkcji administracji, zwanej administracją świadczącą, polegającej na ciągłym i nieograniczonym w czasie zaspokajaniu potrzeb za pomocą działalności ludzkiej, której rezultatem jest zaspokojenie potrzeby określonej najczęściej przez indywidualne cechy odbiorcy, przy czym bezpośredni rezultat wykonywania usługi nie polega na wytworzeniu dobra materialnego" (ibidem, s. 38).

23 S. Fundowicz, Decentralizacja administracji publicznej w Polsce, Lublin 2005, s. 116-123.

${ }^{24}$ Uchwała TK z dnia 27 września 1994 r., sygn. akt W. 10/93, OTK 1994, cz. II, s. 191-194.

25 Ibidem. 
w imieniu całej administracji [...] lecz jako autonomiczny podmiot praw i obowiązków związanych z realizacją przypisanych jej zadań publicznych [...] Nie ulega wątpliwości, że decentralizacja składników ekonomicznych [...] umacnia samorząd jako jednostkę administracji zdecentralizowanej ${ }^{26}$.

\section{W tym kontekście warto przywołać pogląd doktryny, że}

Podstawową formą decentralizacji jest samorząd. Jego istotą jest powierzenie zarządu sprawami publicznymi samym zainteresowanym, czyli zrzeszeniom obywateli, zorganizowanych z mocy ustawy w korporacjach prawa publicznego [...] samorząd jest formą ustrojową wykonywania zarządu sprawami danej korporacji publicznoprawnej przez jej członków ${ }^{27}$.

W doktrynalnej praktyce samorządowej zauważalne są podobne konotacje: „Samorząd w znaczeniu prawnym (korporacyjnym) — rozumiany jako wykonywanie zadań administracji publicznej w sposób zdecentralizowany i na własną odpowiedzialność przez odrębne od państwa podmioty [...]”28. „Podstawową kategorią korporacji jest samorząd, któremu państwo przekazuje znaczną część swojej funkcji administracyjnej, a jednocześnie wyposaża go w osobowość prawną w dziedzinie prawa publicznego" ${ }^{29}$. Należy zauważyć, że zgodnie art. 16 ust. 2 Konstytucji RP: „Samorząd terytorialny uczestniczy w sprawowaniu władzy publicznej. Przysługującą mu w ramach ustaw istotną część zadań publicznych samorząd wykonuje w imieniu własnym i na własną odpowiedzialność”, „czyni samorząd terytorialny współodpowiedzialnym za funkcjonowanie państwa, stanowiąc jednocześnie podstawy współpracy organów władzy wykonawczej — aparatu centralnego i zdecentralizowanych struktur samorządowych"30.

\section{W ujęciu M. Kuleszy}

samorząd i decentralizacja stanowią podstawę samodzielnego zarządzania sprawami publicznymi przede wszystkim w rozumieniu gospodarczym, w systemie sieciowym, a nie hierarchicznym, przez osiąganie korzyści społecznych i gospodarczych w skali lokalnej czy regionalnej, poprzez działanie na rzecz rozwoju danej jednostki samorządu terytorialnego, organizowanie dostarczania usług publicznych, współdziałanie i zarazem konkurowanie z innymi samorządami, udział w rynkach ponadlokalnych i ponadregionalnych itp. ${ }^{31}$

„Jest wyrazem nowoczesnego podejścia do zarządzania publicznego, elementem nowoczesnej organizacji i funkcjonowania państwa o zdecentralizowanej strukturze, której nie można pomijać w kształtowaniu nowoczesnych struktur

26 E. Knosala, Organizacja administracji publicznej. Studium z nauki administracji i prawa administracyjnego, Sosnowiec 2005, s. 97.

27 H. Izdebski, M. Kulesza, Administracja publiczna. Zagadnienia ogólne, Warszawa 2004, s. $136-137$.

28 B. Dolnicki, Samorząd terytorialny, Kraków 2006, s. 17.

29 J. Zimmermann, Prawo administracyjne, Kraków 2006, s. 109.

30 K. Kokocińska, Decentralizacja jako ustrojowa zasada relacji pomiędzy organami władzy publicznej, „Ruch Prawniczy, Ekonomiczny i Socjologiczny” 2006, nr 2, s. 27.

31 M. Kulesza, O tym, ile jest decentralizacji w centralizacji, a takze o osobliwych nawykach uczonych administratywistów, [w:] Między tradycją a przyszłością..., s. 415. 
organizacji działań"32. Zadania własne wykonywane przez j.s.t. polegają na zaspokajaniu potrzeb wspólnoty samorządowej (art. 166 ust. 1 Konstytucji RP).

$\mathrm{W}$ tym miejscu pojawią się pytania o zakres i stopień samodzielności j.s.t. w kwestii oświaty lokalnej samorządów, o wpływ reform ustrojowo-systemowych na decentralizację zarządzania oświatą, o kierunek zmiany dotychczasowej polityki oświatowej państwa na tle reformy edukacji ${ }^{33}$, o wyzwania stojące przed j.s.t., o rolę strategii rozwoju edukacji lokalnej i sposobów realizacji zadań publicznych ${ }^{34}$. Dodajmy, że jednostki samorządu terytorialnego ustawodawca (art. 3 pkt 5 u.s.o.) określa jako organ prowadzący szkołę lub placówkę. Ponadto posługuje się ustawowym określeniem ,zadania oświatowe jednostek samorządu terytorialnego" (art. 3 pkt 14 u.s.o.) przez które należy rozumieć „zadania w zakresie kształcenia, wychowania i opieki, w tym profilaktyki społecznej”. Zgodnie z art. 5 ust. 3 u.s.o. jednostki samorządu terytorialnego mogą zakładać i prowadzić jedynie szkoły i placówki publiczne. Powstaje pytanie o wpływ polityki oświatowej na decentralizację zarządzania oświatą, której towarzyszą zmienne uwarunkowania administracji publicznej w edukacji publicznej, niestabilność prawa oświatowego, nieprzewidywalność polityki oświatowej państwa w zakresie reformy edukacji, polityczne instrumentalizowanie edukacji publicznej. To tylko wybrane determinanty wpływające na politykę oświatową samorządu terytorialnego i sposoby realizacji zadań w zakresie edukacji publicznej. Można wstępnie skonstatować, że oświata samorządowa jako sfera działania administracji publicznej na przełomie ostatnich lat zmienia się dynamicznie i niejednokrotnie stwarza wyraźny dysonans między oczekiwaniami a zaspokojeniem uniwersalnych potrzeb w edukacji ${ }^{35}$. Nie można określić zakresu zadań oświatowych raz na zawsze, albowiem, co wynika z niniejszych rozważań, mają one charakter dynamiczny. Dynamiczność zadań oświatowych wynika ze zmian ustrojowo-społecznych, zmian polityki edukacyjnej państwa, a zwłaszcza z nieprzewidywalności reform edukacji.

Najważniejszą zmianą wdrażaną w związku z reformą edukacji jest zmiana kształtu ustroju szkolnictwa. W nowej strukturze ustroju szkolnego będą funkcjo-

${ }^{32}$ K. Kokocińska, op. cit., s. 28.

33 Zob. A. Piszko, Nowa struktura szkolnictwa, LEX/El. 2016 (dostęp: 15.01.2017); Dobra szkoła. Reforma edukacji. Najważniejsze zmiany. Pytania i odpowiedzi, www.reformaedukacji.men. gov.pl (dostęp: 15.01.2017).

34 Zob. R. Raszewska-Skałecka, Decentralizacja publicznych zadań oświatowych a zawodność państwa, [w:] Państwo i rynek. Obszary zawodności, red. U. Kalina-Prasznic, Wrocław 2011, s. 105-137; eadem, Decentralizacja zadań oświatowych..., [w:] Administracja publiczna wobec..., s. 145-164; eadem, Przestrzeń administracji świadczacej w sferze oświaty samorzadowej, [w:] Przestrzeń w prawie administracyjnym, red. J. Zimmermann, Warszawa 2013, s. 238-260.

35 Zob. R. Raszewska-Skałecka, Wybrane problemy administracji świadczacej $w$ zakresie wykonywania zadań oświatowych przez jednostki samorządu terytorialnego, „Przegląd Prawa i Administracji”, AUW No 3661, t. C/1, Wrocław 2015, s. 127-148; eadem, Niepewność w oświacie jako antywartość w prawie administracyjnym, [w:] Antywartości w prawie administracyjnym, red. A. Błaś, Warszawa 2016, s. 271-291. 
nować następujące typy szkół publicznych i niepublicznych: 1) ośmioletnia szkoła podstawowa; 2) szkoły ponadpodstawowe: a) czteroletnie liceum ogólnokształcące, b) pięcioletnie technikum, c) trzyletnia szkoła branżowa I stopnia, d) trzyletnia szkoła specjalna przysposabiająca do pracy, e) dwuletnia szkoła branżowa II stopnia, f) szkoła policealna ${ }^{36}$. W dotychczasowej strukturze szkolnictwa nastąpi stopniowa eliminacja gimnazjów z systemu oświaty, zwana wygaszaniem gimnazjów $^{37}$. Zmiany ustroju szkolnego wymagają dostosowania sieci szkół prowadzonych przez gminę do nowej struktury szkolnictwa, o których mowa w art. 206-212 ustawy z dnia 14 grudnia 2016 r. - Przepisy wprowadzające ustawę - Prawo oświatowe (Dz.U. 2017 poz. 60). Przepisy wprowadzające określają, w jaki sposób gmina powinna dostosować sieć szkół podstawowych i gimnazjów do nowego ustroju szkolnego i w jakim terminie ustawowym. Z kolei podstawy prawne dostosowania sieci szkół powiatowych do nowej struktury szkolnictwa określają art. 213-217 u.p.w.p.o. Gminy ${ }^{38}$ i powiaty ${ }^{39}$ zobligowane są w ustawowym termi-

36 Zob. art. 18 ust. 1 p.o.; art. 1 u.p.w.p.o.: „Ustawa z dnia 14 grudnia 2016 r. — Prawo oświatowe (Dz.U. 2017 poz. 59) wchodzi w życie z dniem 1 września 2017 r., z wyjątkiem: 1) art. 18 ust. 4 , art. 47 ust. 3 pkt 2 oraz rozdziału 6, które wchodzą w życie po upływie 14 dni od dnia ogłoszenia; 2) art. 47 ust. 1 pkt 1 lit. c, d i g oraz pkt 4, które wchodzą w życie z dniem 1 września 2018 r."

37 „Stopniowe wygaszanie gimnazjów rozpocznie się od roku szkolnego 2017/2018 i tym samym w kolejnych latach rekrutacja do tych szkół nie będzie już prowadzona. 1 września 2017 r. uczniowie kończący w roku szkolnym 2016/2017 klasę szóstą szkoły podstawowej staną się uczniami siódmej klasy szkoły podstawowej. W roku szkolnym 2018/2019 ostatni rocznik dzieci klas trzecich ukończy gimnazjum. Od 1 września 2019 r. w ustroju szkolnym gimnazja nie będą już funkcjonować. Od 1 września 2017 r. planuje się wprowadzenie branżowej szkoły I stopnia w miejsce zasadniczej szkoły zawodowej. Wprowadzenie branżowej szkoły II stopnia dla absolwentów branżowej szkoły I stopnia rozpocznie się od roku szkolnego 2020/2021", www.reformaedukacji.men.gov.pl (dostęp: 15.01.2017).

38 Zgodnie z art. 206 ust. 1 u.p.w.p.o.: „Rada gminy podejmuje uchwałę w sprawie projektu dostosowania sieci szkół podstawowych i gimnazjów do nowego ustroju szkolnego, wprowadzonego ustawą - Prawo oświatowe”. W świetle art. 210 ust. 1 u.p.w.p.o.: „Rada gminy po uzyskaniu pozytywnej opinii kuratora oświaty, o której mowa w art. 208 ust. 3 i 4, w terminie do dnia 31 marca 2017 r. podejmuje uchwałę w sprawie dostosowania sieci szkół podstawowych i gimnazjów do nowego ustroju szkolnego, wprowadzonego ustawą - Prawo oświatowe, na okres od dnia 1 września 2017 r. do dnia 31 sierpnia 2019 r.”; zob. A. Piszko, Uchwały w sprawie dostosowania sieci szkót do nowego ustroju szkolnego. Dostosowanie sieci szkót prowadzonych przez gminę w świetle nowych regulacji prawnych, https://sip.lex.pl/\#/analiza/738427166/uchwaly-w-sprawie-dostosowania-sieci -szkol-do-nowego-ustroju-szkolnego (dostęp: 15.01.2017).

39 Zgodnie z art. 213 ust. 1 u.p.w.p.o.: „Rada powiatu podejmuje uchwałę w sprawie projektu dostosowania sieci szkół ponadgimnazjalnych i specjalnych do nowego ustroju szkolnego, wprowadzonego ustawą - Prawo oświatowe oraz ustalenia sieci szkół ponadpodstawowych i specjalnych”. W świetle art. 217 ust. 1 u.p.w.p.o.: „Rada powiatu po uzyskaniu pozytywnej opinii kuratora oświaty, o której mowa w art. 215 ust. 3 i 4, w terminie do dnia 31 marca 2017 r. podejmuje uchwałę w sprawie dostosowania sieci szkół ponadgimnazjalnych i specjalnych do nowego ustroju szkolnego wprowadzonego ustawą - Prawo oświatowe oraz ustalenia sieci szkół ponadpodstawowych i specjalnych, na okres od dnia 1 września 2017 r. do dnia 31 sierpnia 2019 r."; zob. A. Piszko, Uchwaty w sprawie dostosowania sieci szkót do nowego ustroju szkolnego... 
nie do 31 marca 2017 r. przeprowadzić proces dostosowania sieci szkół do nowego ustroju szkolnego. Edukacja publiczna w ramach decentralizacji zarządzania strukturami państwa jest zadaniem publicznym j.s.t. ${ }^{40}$ Ponadto „ustawowo określony publiczny charakter zadań j.s.t. wskazuje na ich miejsce w sferze realizacji we-

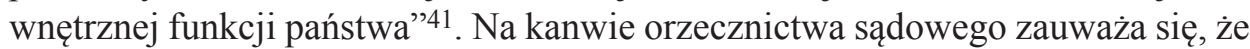

Podejmując $w$ ramach decentralizacji funkcji państwa decyzję o przekazaniu gminom zakładania i prowadzenia publicznych szkół podstawowych i przedszkoli z dniem 1 stycznia 1994 r., ustawodawca określił jednocześnie charakter przekazanych przez państwo zadań jako obowiązkowe zadania własne gmin (art. 104 ust. $1 \mathrm{i}$ art. 105 u.s.o.). W związku z powyższym, przepis art. 5 ust. 5 u.s.o. stanowiący, że zakładanie i prowadzenie publicznych przedszkoli, szkół podstawowych oraz gimnazjów należy do zadań własnych gmin należy rozumieć w sposób jednoznaczny, iż podmiotem obowiązanym do zakładania i prowadzenia publicznych szkół podstawowych, gimnazjów i przedszkoli jest gmina. Obowiązek gminy polegający na zakładaniu i prowadzeniu publicznych placówek oświatowych nie może być przekazany odrębnej osobie prawnej ${ }^{42}$.

\section{Należy dodać, że}

Obowiązkowy charakter zadań własnych gminy w postaci prowadzenia szkół podstawowych i przedszkoli powoduje, że gmina nie może z wykonywania tych zadań zrezygnować, czy też przekazać ich do wykonania innemu podmiotowi, nawet fundacji, na której powstanie i działalność będzie wywierała znaczący wpływ ${ }^{43}$.

\section{Należy zgodzić się z T. Bąkowskim, że to}

zadania publiczne, a ściślej ich realizację należy uznać za rację bytu administracji publicznej. [...] Charakter, liczba, przedmiot oraz specyfika tych zadań powinny stanowić odzwierciedlenie potrzeb społeczeństwa i państwa. Potrzeb, których efektywne i sprawne zaspokajanie ma być udziałem struktur aparatu administracji publicznej" 44 .

Należy się zgodzić z autorem, że potrzeby te, przedkładane na zadania publiczne powierzone do wykonania administracji publicznej, nie mają stałego charakteru. Ten brak stałości zadań publicznych wiąże się na przykład z rozwojem cywilizacyjnym, koniunkturą gospodarczą, sytuacją polityczną, przeobrażeniami kulturowymi, zmianami klimatycznymi czy z wieloma innymi czynnikami ${ }^{45}$. Warto wskazać, że zmiany edukacyjne, w tym przekształcenia szkół oraz konieczność

40 Zob. R. Raszewska-Skałecka, Decentralizacja zadań..., s. 145; Sposoby realizacji zadań publicznych, red. B. Dolnicki, Warszawa 2017, s. 16. Autor zwraca uwagę na rozróżnienie w ustawach samorządowych dwóch pojęć: zadania i kompetencje. Zdaniem B. Dolnickiego „biorąc pod uwagę racjonalność ustawodawcy [...], „zadanie to określony cel, który musi osiągnąć samorząd, natomiast kompetencja to zespół praw i obowiązków organu, obejmujących prawne formy działania - czyli formy realizacji zadań. Zadania samorządu terytorialnego mają charakter publiczny" (ibidem, s. 16).

41 Ibidem.

42 Wyrok NSA w Warszawie z dnia 5 grudnia 2006 r., I OSK 1377/06, LEX nr 320841.

43 Wyrok NSA w Warszawie z dnia 9 lutego 2006 r., I OSK 1372/05, LEX nr 194880. Nie można zlikwidować w trybie art. 59 ust. 1 ustawy z dnia 7 września 1991 r. o systemie oświaty (Dz.U. 2004 $\mathrm{Nr} 256$, poz. 2572 ze zm.) wszystkich szkół i placówek na terenie gminy, prowadzonych przez gminę.

44 Organizacja administracji publicznej z perspektywy powierzonych jej zadań, red. T. Bąkowski, Warszawa 2015, s. 15.

45 Ibidem. 
dostosowania sieci szkół do zmiany struktury, wynikają ze zmiennego otoczenia administracji publicznej i edukacji, a zwłaszcza z nieprzewidywalności polityki oświatowej w realizacji zadań oświatowych. Podkreślmy za T. Bąkowskim, że

dobra administracja to administracja ustawicznie i właściwie reagująca na dokonujące się przemiany w jej otoczeniu, któremu służy, dostosowująca swoje struktury, a także sposoby i metody działania do aktualnych potrzeb adresatów jej działalności ${ }^{46}$.

Największe znaczenie w organizowaniu i świadczeniu usług, jak pisze T. Kuta, mają samorządy terytorialne i ich organy wyposażone w ustawowy zakres działania i kompetencje. Zdaniem autora

Samorząd terytorialny w Polsce mógłby sprawniej działać w organizowaniu i świadczeniu usług, gdyby organy rządowe nie wprowadzały coraz to nowych zmian, w dodatku wszystkich jednocześnie (z reformą podziału terytorialnego na czele) ${ }^{47}$.

Zmiana systemowa nie ominęła oświaty samorządowej. Lata 90 . w zakresie decentralizacji władzy publicznej przyniosły zarówno decentralizację zarządzania oświatą w obszarze kształtowania lokalnej polityki oświatowej, jak i odpowiedzialność władz samorządowych za lokalną oświatę ${ }^{48}$. Edukacja publiczna w ramach decentralizacji zarządzania strukturami państwa stała się zadaniem oświatowym jednostek samorządu terytorialnego, uregulowanym w przepisach samorządowych ustaw ustrojowych i w przedmiotowej ustawie o systemie oświaty.

\section{ROLA POLITYKI ADMINISTRACYJNEJ — POLITYKI OŚWIATOWEJ W WYKONYWANIU ZADAŃ OŚWIATOWYCH}

\section{Administracja publiczna wykonuje}

zadania tak ważne dla prawidłowego funkcjonowania życia zbiorowego, że stale musi dotrzymywać kroku zmianom zachodzącym w środowisku społecznym, któremu służy. Jest to przy tym złożony system organizacyjny o skomplikowanych wewnętrznych powiązaniach i wielostronnych związkach z otaczającym światem, którego jest częścią. Do zadań administracji publicznej [...] należy realizacja wielu istotnych świadczeń o charakterze społecznym, a także odpowiedzialność za poziom usług publicznych, od których w zasadniczym stopniu zależy właściwe funkcjonowanie życia zbiorowego ${ }^{49}$.

\section{Ibidem}

47 T. Kuta, Rola administracji ustug $w$ zaspokajaniu potrzeb socjalno-bytowych $i$ oświatowo-kulturalnych obywateli, [w:] Administracja publiczna u progu XXI wieku, red. Z. Niewiadomski, Przemyśl 2000, s. 341.

48 Zob. P. Chmielnicki, op. cit.; D. Kurzyna-Chmiel, op. cit.; R. Raszewska-Skałecka, Decentralizacja zadań..., s. 145-170; P. Lisowski, Organizacja administracji publicznej wobec zadań oświatowych jednostek samorzadu terytorialnego, [w:] Organizacja administracji publicznej..., s. $447-475$.

49 H. Izdebski, M. Kulesza, Administracja publiczna. Zagadnienia ogólne, wyd. 3, Warszawa 2004, s. 329. 
Administracja jest organizatorem zaspokajania potrzeb społeczeństwa, np. w sferze oświaty, i elementem systemu politycznego, jest warunkowana przez politykę $e^{50}$. Każda funkcja administracji w swej praktycznej realizacji musi wiązać się z programowymi założeniami politycznymi administracji państwowej ${ }^{51}$. Administracja ma charakter polityczny w dwojakim sensie: „ona sama jest zjawiskiem ze sfery stosunków politycznych i że jej działanie służy osiąganiu celów publicznych" 52 .

Co prawda pojęcie polityki jest wieloznaczne, jednakże spróbujmy je odnieść do polityki administracyjnej. Dla wyodrębnienia polityki administracyjnej przydatne jest pojęcie polityki w znaczeniu:

wytyczne kierunku działalności państwa przez organy określone w konstytucji, same programy określające kierunek takiej działalności, chociaż pojęcie polityki może jeszcze oznaczać sztukę skutecznej działalności w sferze życia społecznego, działalność związaną z dążeniem do zdobycia władzy państwowej ${ }^{53}$.

\section{Zdaniem J. Bocia}

Polityka jest to aprobowany przez organy państwowe i samorządowe system pozaprawnych i postulatywnych wypowiedzi o tym, gdzie, kiedy i jak korzystać z materialnych i organizacyjnych możliwości państwa i samorządów terytorialnych ${ }^{54}$.

\section{Jan Jeżewski poszerza ten kontekst określenia, rozumiejąc politykę jako}

wiedzę i umiejętność, polegającą na konstatacji (opisie) stanu spraw publicznych w wyodrębnionej dziedzinie, ich analizie i ocenie (według racjonalnych i wewnętrznie spójnych kryteriów), a następnie sformułowaniu programu (w praktyce używane są też określenia: założenia, koncepcje, studia, plany) wskazującego cele, sposoby i środki ich osiągnięcia, pożądane z uwagi na dokonaną ocenę stanu spraw publicznych ${ }^{55}$.

\section{Wypada zaznaczyć, że przedmiotem polityki administracyjnej jest}

przewidywanie skutków działania i wykorzystywanie możliwości działania w ramach prawa, przygotowywanie programów działania administracji oraz weryfikacja ich realizacji i ocenianie oraz wartościowanie metod i sposobów pracy, a także wysuwanie postulatów dotyczących zmian w całokształcie administracji ${ }^{56}$.

50 Zob. J. Łukasiewicz, Podstawowe pojęcia z zakresu nauki administracji, [w:] Encyklopedia prawa administracyjnego, red. M. Domagała, A. Haładyj, S. Wrzosek, Warszawa 2010, s. 37; idem, Stowo wstępne, [w:] Polityka administracyjna, red. J. Łukasiewicz, Rzeszów 2008, s. 13; idem, W sprawie wymiarów racjonalności polityki administracyjnej, [w:] Polityka administracyjna ..., s. 429-437; R. Raszewska-Skałecka, Polityka administracyjna w sferze administracji świadczacej-wybrane zagadnienia, „Przegląd Prawa i Administracji”. AUW No 2502, t. LIV, s. 237-274.

51 Zob. T. Kuta, Funkcje wspótczesnej administracji i sposoby ich realizacji, Wrocław 1992, s. 14 .

52 A. Błaś, J. Boć, J. Jeżewski, Administracja publiczna, red. J. Boć, Wrocław 2004, s. 315.

53 J. Jeżewski, Polityka administracyjna. Zagadnienia podstawowe, [w:] Administracja publiczna..., s. 298.

54 Administracja publiczna..., red. J. Boć, s. 315.

55 J. Jeżewski, Polityka administracyjna..., s. 315.

56 J. Szreniawski, Wstęp do nauki administracji, Lublin 2002, s. 10. 
Do niej należy poszukiwanie optymalnych rozwiązań w sferze spraw znajdujących się w kompetencjach administracji publicznej ${ }^{57}$. Przyznane kompetencje zaś są jej obowiązkami i nałożonych zadań nie może nie realizować ${ }^{58}$. Znajomość polityki administracyjnej umożliwia sprawne funkcjonowanie w strukturach administracyjnych i pozwala radzić sobie w poszczególnych procesach administrowania ${ }^{59}$. Istotą polityki administracyjnej jest tworzenie programów działania administracji publicznej w poszczególnych sferach jej funkcjonowania, w tym w dziedzinie oświaty i nauki. Do niej należą wskazówki dotyczące usprawnienia administracji publicznej w sferze oświaty. Należy zauważyć, że cele i założenia polityki administracyjnej w danym dziale administracji przenikają do niej przede wszystkim w formie ustaw ${ }^{60}$. Nie sposób mówić o polityce administracyjnej bez prymatu prawa powszechnie obowiązującego, który, jak pisze A. Błaś, odnosi się też do polityki administracyjnej pojmowanej tradycyjnie jako sfera dokonywania przez organy administracyjne wyboru najlepszych sposobów wykonywania prawnie określonych zadań administracyjnych - na podstawie i w granicach, które określa prawo powszechnie obowiązujące ${ }^{61}$. W ocenie wskazanego autora „prawo jest podstawą działan objętych pojęciem polityki administracyjnej, w prawie powszechnie obowiązującym zawarte jest określenie zasad i kryteriów, a także form i zakresu jej prowadzenia"62. Przypomnijmy, że w piśmiennictwie i judykaturze zauważa się, że

państwo i jego administracja w pierwszym rzędzie winno gwarantować obywatelowi pewność jego sytuacji prawnej i zapewniać mu bezpieczeństwo prawne. Prawo stanowione i działania władz publicznych winny umacniać zaufanie obywateli do państwa i do działań jego organów ${ }^{63}$.

Dodajmy, że przedmiotem polityki administracyjnej jest administrowanie, a to oznacza, że należy mieć na uwadze udział administracji w kształtowaniu tej polityki ${ }^{64}$. Impulsem do zajęcia się przedmiotowym problemem jest też kwestia uczestnictwa administracji w kształtowaniu zmian polityki oświatowej, w tym oświaty samorządowej w zakresie wykonywanych zadań oświatowych. Mając też na uwadze gwarancje konstytucyjne, należy zastanowić się, czy współcześnie w procesach reformatorskich państwa i jego administracji publicznej nie mamy do czynienia z traktowaniem prawa jako instrumentu polityki oświatowej.

57 M. Ganczar, Wplyw informatyzacji na polityke administracyjna, [w:] Polityka administracyjna..., s. 207.

58 J. Szreniawski, op. cit., s. 9.

59 M. Ganczar, op. cit., s. 207.

60 Z. Leoński, Nauka administracji, Warszawa 2004, s. 18.

61 A. Błaś, Państwo prawa i polityka administracyjna, [w:] Polityka administracyjna ..., s. 141.

62 Ibidem, s. 144.

63 Ibidem, s. 142; zob. wyrok z dnia 14 czerwca 2000 r., sygn. P. 3/00. Tekst sentencji opublikowany został w Dz.U. $2000 \mathrm{Nr}$ 50, poz. 600.

64 J. Jeżewski, Polityka administracyjna ..., s. 291. 
Przykładem polityki administracyjnej w zakresie polityki oświatowej samorządowej jest przyjęta przez Radę Miejską Wrocławska Strategia Edukacyjna, jako załącznik do uchwały NR XV/271/15 Rady Miejskiej Wrocławia z dnia 3 września 2015 r. w sprawie Wrocławskiej Strategii Edukacyjnej (dalej: WSE). Wykonanie uchwały powierzono prezydentowi miasta ${ }^{65}$. Strategia stanowi deklarację głównych kierunków rozwoju wrocławskiej edukacji, określając jej założenia i cele (cel strategiczny i cele szczegółowe, czyli obszary priorytetowe) do realizacji, a sposoby ich osiągania dostosowując do możliwości i założeń polityki społeczno-gospodarczej miasta ${ }^{66}$. WSE wskazuje generalne kierunki rozwoju edukacji, rozumianej jako „system wartości, norm i znaczeń, fundamentalnych założeń będących stymulatorami dla szkół i placówek oraz partnerów współuczestniczących w procesie edukacji”. Celem strategicznym przyjętym w WSE jest „stworzenie warunków dla funkcjonowania systemu edukacji o najwyższych standardach wychowania i kształcenia poprzez rozwój wrocławskiej kultury edukacyjnej”, zaś „obszarami priorytetowymi w ramach celów szczegółowych są: nauczyciel, kultura szkolna, relacje edukacji i rynku pracy, świadomy obywatel, kultura czasu wolnego". Punktem wyjścia przy tworzeniu WSE były wartości kluczowe przyjęte w polityce miejskiej: „Tożsamość, Talent, Technologia, Tolerancja”. W deklaracji WSE podkreśla się znaczenie edukacji dla jednostki, wskazując, iż

nie oznacza dzisiaj wyposażenia jednostki w zamknięty zestaw wiedzy i kwalifikacji, ale kształcenie umiejętności krytycznego myślenia, przetwarzania informacji, odnajdywania rozwiązań problemów, a przede wszystkim umiejętności uczenia się przez całe życie.

Polityka oświatowa określona w WSE powinna być kompatybilna z założeniami polityki społeczno-gospodarczej Wrocławia na 2017 rok, w której przyjęte zostały strategiczne przedsięwzięcia w ramach trzech obszarów priorytetowych, obejmujących cele szczegółowe rozwoju społeczno-gospodarczego miasta, tj.: „Europejska metropolia - miasto nowoczesnych przedsięwzięć”; „Gospodarka innowacyjna i rozwój" skupiająca projekty wspomagające budowanie gospodarki opartej na wiedzy oraz przedsięwzięcia komunikacyjne, służące rozwojowi miasta oraz „Budowa kapitału społecznego, poprawa jakości życia mieszkańców. Skupia on wysiłki związane z opieką zdrowotną i socjalną, edukacją, kulturą, bezpieczeństwem publicznym, organizacjami pozarządowymi czy rewitalizacją miasta" 67 .

65 http://uchwaly.um.wroc.pl/uchwala.aspx?numer=XV/271/15; http://wrosystem.um.wroc. pl/beta_4/webdisk/179742/0271ru07.pdf; Biuletyn Urzędowy RMW z 2015 r. poz. 252, http://bip. um.wroc.pl/artykuly/631/polityki-miejskie (dostęp: 31.01.2017).

66 Uchwała NR XXX/609/16 Rady Miejskiej Wrocławia z dnia 15 września 2016 r. w sprawie „Założeń polityki społeczno-gospodarczej Wrocławia na rok budżetowy 2017”, Biuletyn Urzędowy RMW z 2016 r. poz. 230.

67 Biuletyn Urzędowy RMW z 2016 r. poz. 230, http://bip.um.wroc.pl/artykul/364/25379/zalozenia-polityki-spoleczno-gospodarczej-wroclawia-na-rok-2017 (dostęp: 31.01.2017). 
Samorządy, jak podkreśla C. Trutkowski, powinny traktować szkoły ,jako instytucje budujące lokalny kapitał społeczny”68. Zdaniem autora „konieczna wydaje się zmiana paradygmatu edukacji, odejście od postrzegania placówek oświatowych przez pryzmat miejsc wyposażających wyłącznie w określony zasób wiedzy na rzecz myślenia o szkole jako instytucji budującej lokalny kapitał społeczny"69. Aktywną rolę w tym procesie powinny, jak twierdzi autor, odgrywać władze lokalne, albowiem ,świadoma lokalna polityka oświatowa nie jest jednak możliwa bez redefinicji koncepcji szkoły"70.

\section{POLITYKA OŚWIATOWA PAŃSTWA A SAMORZĄDOWE ZADANIA OŚWIATOWE}

Minister właściwy do spraw oświaty i wychowania (MEN) wykonuje zadania w zakresie polityki oświatowej. Zgodnie z art. 21 u.s.o.: „koordynuje i realizuje politykę oświatową państwa i współdziała $\mathrm{w}$ tym zakresie $\mathrm{z}$ wojewodami oraz z innymi organami i jednostkami organizacyjnymi właściwymi w sprawach funkcjonowania systemu oświaty". Na podstawie art. 35 ust. 2 pkt 1 ustawy z dnia 7 września 1991 r. u.s.o. (Dz.U. 2016 poz. 1943 z późn. zm.) $)^{71}$ określone zostały zmiany podstawowych kierunków realizacji polityki oświatowej państwa w roku szkolnym 2016/2017, wskazane w piśmie DKOWNP.4092.58.2016.DB z dnia 7 lipca 2016 r. $^{72}$, ustalając: 1) upowszechnianie czytelnictwa, rozwijanie kompetencji czytelniczych wśród dzieci i młodzieży; 2) rozwijanie kompetencji informatycznych dzieci i młodzieży w szkołach i placówkach; 3) kształtowanie postaw, wychowanie do wartości; 4) podniesienie jakości kształcenia zawodowego w szkołach ponadgimnazjalnych poprzez angażowanie pracodawców w proces dostosowania kształcenia zawodowego do potrzeb rynku pracy; 5) przygotowanie do wdrożenia od roku szkolnego 2017/2018 nowej podstawy programowej.

W założeniach reformy edukacji MEN przyjmuje się, że

68 Samorzady powinny traktować szkoty jako instytucje budujace lokalny kapitat społeczny, http://www.samorzad.lex.pl/czytaj/-/artykul/samorzady-powinny-traktowac-szkoly-jako-instytucje -budujace-lokalny-kapital-spoleczny/3?refererPlid=5227823 (dostęp: 31.01.2017); C. Trutkowski, Kształtowanie polityki oświatowej samorządów lokalnych, ST 2015, nr 1-2, s. 44-53.

69 C. Trutkowski, op. cit., s. 44.

70 Ibidem.

71 Zgodnie z art. 35 ust. 2 pkt 1 u.s.o.: ,[...] minister właściwy do spraw oświaty i wychowania w szczególności: 1) ustala podstawowe kierunki realizacji polityki oświatowej państwa, w tym zadania z zakresu nadzoru pedagogicznego".

72 Zob. MEM, pismo z dnia 24 stycznia 2017 r., DKO-WNP.4092.58.2016.DB, https://men. gov.pl/jakosc-edukacji/nadzor-pedagogiczny/podstawowe-kierunki-realizacji-polityki-oswiatowej -panstwa-w-roku-szkolnym-2016_2017.html (dostęp: 26.01.2017). 
przygotowana reforma edukacji wychodzi naprzeciw oczekiwaniom większości Polaków [...] Zmiany są przemyślane i zaplanowane na wiele lat. Zależy nam na tym, aby każdy uczeń [...] miał dobrą szkołę i dobrą edukację. Reforma edukacji to nie tylko zmiana ustroju szkolnego. To także propozycja nowych rozwiązań w rozwoju szkolnictwa zawodowego silnie powiązanego z rynkiem pracy oraz zmiany w organizacji i funkcjonowaniu szkół i placówek oświatowych ${ }^{73}$.

\section{Przyjmuje się, że}

ustawa z dnia 14 grudnia 2016 r. - Prawo oświatowe (Dz.U. poz. 59) i ustawa z dnia 14 grudnia 2016 r. - Przepisy wprowadzające ustawę — Prawo oświatowe (Dz.U. poz. 60) dotyczą zmian w systemie oświaty polegających nie tylko na wprowadzeniu nowego ustroju szkolnego. To także propozycja nowych rozwiązań w systemie szkolnictwa zawodowego, silnie powiązanego z rynkiem pracy oraz zmiany w organizacji i funkcjonowaniu szkół i placówek oświatowych ${ }^{74}$.

\section{Zgodnie z art. 31 ust. 1 pkt 6 u.s.o.}

Kurator oświaty, w imieniu wojewody, wykonuje zadania i kompetencje w zakresie oświaty określone w ustawie i przepisach odrębnych na obszarze województwa, a w szczególności: [...] realizuje politykę oświatową państwa, a także współdziała z organami jednostek samorządu terytorialnego w tworzeniu i realizowaniu odpowiednio regionalnej i lokalnej polityki oświatowej, zgodnych z polityką oświatową państwa.

[...] pełni on w polskim systemie oświaty szczególną rolę organu administracji rządowej, odpowiedzialnego za realizację polityki oświatowej państwa na terenie właściwego województwa, a jednocześnie obarczonego obowiązkiem takiego współtworzenia i realizowania regionalnej i lokalnej polityki oświatowej (art. 31 pkt 6 ustawy z 1991 r. o systemie oświaty), aby ta ostatnia pozostawała w zgodzie z polityką oświatową państwa ${ }^{75}$.

W związku z wprowadzeniem przepisów ustawy Prawo oświatowe oraz ustawy Przepisy wprowadzające ustawę Prawo oświatowe zachodzi konieczność ustalenia przez jednostki samorządu terytorialnego planów sieci publicznych szkół i przedszkoli. Kurator oświaty ${ }^{76}$ opiniuje sieci prowadzonych przez gmi-

73 O reformie, http://reformaedukacji.men.gov.pl/(dostęp: 15.01.2017); Dobra szkoła. Reforma edukacji. Najważniejsze zmiany. Pytania i odpowiedzi, Warszawa 2016, s. 8. Wynika z tego, że „Sprawne i efektywne wprowadzenie nowej struktury szkolnictwa wymaga kilkuletniego okresu przejściowego. Umożliwi on dostosowanie obecnie istniejącego systemu oświaty do nowych rozwiązań ustrojowych".

74 Departament Informacji i Promocji, Ministerstwo Edukacji Narodowej, http://reformaedukacji.men.gov.pl/. Zgodnie z art. 189 ustawy z dnia 14 grudnia 2016 r. p.o. (Dz.U. poz. 59): „Ustawa wchodzi w życie w terminie i na zasadach określonych w ustawie z dnia 14 grudnia $2016 \mathrm{r}$. u.p.w.p.o. (Dz. U. z 2017 r. poz. 60)". Ustawodawca przyjął w art. 1 ustawy z dnia 14 grudnia 2016 r. u.p.w.p.o. (Dz. U. z dnia 11.01.2017 r. poz. 60), że: „Ustawa z dnia 14 grudnia 2016 r. p.o. (Dz. U. z dnia 11.01. 2017 r. poz. 59) wchodzi w życie z dniem 1 września 2017 r., z wyjątkiem: 1) art. 18 ust. 4, art. 47 ust. 3 pkt 2 oraz rozdziału 6, które wchodzą w życie po upływie 14 dni od dnia ogłoszenia; 2) art. 47 ust. 1 pkt 1 lit. c, d i g oraz pkt 4, które wchodzą w życie z dniem 1 września 2018 r." (dostęp: 15.01.2017).

75 Zob. wyrok NSA w Warszawie z dnia 5 grudnia 2006 r., sygn. akt I OSK 1377/06, LEX nr 320841 .

76 Zgodnie z art. 3 pkt 8 u.s.o. ustawodawca przez kuratora oświaty rozumie „kierownika kuratorium oświaty jako jednostki organizacyjnej wchodzącej w skład zespolonej administracji rządowej w województwie". 
nę publicznych szkół i przedszkoli. Należy podkreślić, że zgodnie z art. 1 pkt 2 lit. b w zakresie art. 14 ust. 3 b w związku z art. 14 ust. 1 pkt 2 ustawy z dnia 29 grudnia 2015 r. o zmianie ustawy o systemie oświaty oraz niektórych innych ustaw (Dz.U. 2016 poz. 35) statuuje z dniem 1 września 2017 r. dzieciom w wieku 3-5 lat prawo do korzystania $\mathrm{z}$ wychowania przedszkolnego w przedszkolu, oddziale przedszkolnym w szkole podstawowej lub innej formie wychowania przedszkolnego. Jednocześnie art. 14 a ust. 1 u.s.o. (tekst jedn. Dz.U. 2016 poz. 1943 z późn. zm.) w sprawie sieci publicznych przedszkoli, inne formy wychowania przedszkolnego) zobowiązuje radę gminy do ustalenia sieci prowadzonych przez gminę publicznych przedszkoli i oddziałów przedszkolnych w szkołach podstawowych wraz z publicznymi przedszkolami, oddziałami przedszkolnymi w publicznych szkołach podstawowych i publicznymi innymi formami wychowania przedszkolnego, prowadzonymi przez osoby prawne niebędące j.s.t. lub osoby fizyczne, publicznymi innymi formami wychowania przedszkolnego, prowadzonymi przez gminę, niepublicznymi przedszkolami, o których mowa w art. 90 ust. 1b u.s.o., oddziałami przedszkolnymi w niepublicznych szkołach podstawowych, o których mowa w art. 90 ust. 1 ba u.s.o., oraz niepublicznymi innymi formami wychowania przedszkolnego, o których mowa w art. 90 ust. 1c u.s.o. Powinna ona zapewniać dzieciom w wieku od 3 do 6 lat zamieszkałym na obszarze gminy możliwość korzystania z wychowania przedszkolnego. Zgodnie z art. 17 ust. 7 u.s.o. „Ustalenie planu sieci publicznych szkół, o którym mowa w ust. 4 i 5, następuje po uzyskaniu pozytywnej opinii kuratora oświaty o zgodności planu z warunkami określonymi odpowiednio w ust. 1, 2 i 5"77.

W sprawie projektu dostosowania sieci szkół podstawowych i gimnazjów do nowego ustroju szkolnego, wprowadzonego ustawą Prawo oświatowe, należy wskazać, że podstawę projektu uchwały rady gminy ma stanowić art. 206

77 W świetle art. 17 ust. 1 i 2 u.s.o.: „Sieć publicznych szkół powinna być zorganizowana w sposób umożliwiający wszystkim dzieciom spełnianie obowiązku szkolnego, z uwzględnieniem ust. 2. Droga dziecka z domu do szkoły nie może przekraczać: 1) $3 \mathrm{~km}$ - w przypadku uczniów klas I-IV szkół podstawowych; 2) 4 km — w przypadku uczniów klas V i VI szkół podstawowych oraz uczniów gimnazjów”. Zgodnie z art. 17 ust. 4 u.s.o.: „Rada gminy, z uwzględnieniem ust. 1 i 2 , ustala plan sieci publicznych szkół podstawowych i gimnazjów prowadzonych przez gminę, a także określa granice obwodów publicznych szkół podstawowych i gimnazjów, z wyjątkiem specjalnych, mających siedzibę na obszarze gminy, z zastrzeżeniem art. 58 ust. 2. W przypadku publicznych szkół podstawowych i gimnazjów prowadzonych przez inne organy, określenie granic ich obwodów następuje w uzgodnieniu z tymi organami. Uchwała rady gminy podlega ogłoszeniu w wojewódzkim dzienniku urzędowym”. Natomiast art. 17 ust. 5 u.s.o. stanowi, że „Rada powiatu ustala plan sieci publicznych szkół ponadgimnazjalnych oraz szkół specjalnych, z uwzględnieniem szkół ponadgimnazjalnych i specjalnych mających siedzibę na obszarze powiatu prowadzonych przez inne organy prowadzące, tak aby umożliwić dzieciom i młodzieży zamieszkującym na obszarze powiatu lub przebywającym w zakładach i jednostkach, o których mowa w art. 3 pkt 1a lit. b, realizację odpowiednio obowiązku szkolnego lub obowiązku nauki”. 
u.p.w.p.o. ${ }^{78}$ oraz art. 95 p.o. ${ }^{79}$ Dodajmy, że przekształcenie sześcioletnich szkół podstawowych w placówki o strukturze organizacyjnej I-III lub I-IV wymaga zastosowania procedur wskazanych w art. 59 u.s.o. (tekst jedn. Dz.U. 2016 poz. 1943 z późn. zm.). Oznacza to, że do dnia 28 lutego 2017 r. należy przesłać do kuratora oświaty uchwałę intencyjną celem wydania przez kuratora oświaty opinii dotyczącej projektu dostosowania sieci szkół podstawowych i gimnazjów do nowego ustroju szkolnego wprowadzonego ustawą Prawo oświatowe. Na podstawie art. 206 i 208 ustawy z dnia 14 grudnia 2016 r. Przepisy wprowadzające ustawę Prawo oświatowe (Dz.U. 2017 poz. 60) oraz art. 95 ustawy Prawo oświatowe (Dz.U. 2017 poz. 59) kurator oświaty ustala zasady wydawania opinii dotyczącej projektu dostosowania sieci szkół podstawowych i gimnazjów do nowego ustroju szkolnego wprowadzonego ustawą Prawo oświatowe ${ }^{80}$. Ponadto w zakresie projektu dostosowania sieci szkół ponadgimnazjalnych i specjalnych do nowego ustroju szkolnego, wprowadzonego ustawą Prawo oświatowe oraz ustalenia sieci szkół ponadpodstawowych i specjalnych, należy zaznaczyć, że zgodnie z art. 213 Przepisy wprowadzające ustawę Prawo oświatowe ${ }^{81}$ zadaniem powiatu jest opracowanie projektu dostosowania sieci szkół ponadgimnazjalnych i specjalnych do nowego ustroju szkolnego, wprowadzonego ustawą Prawo oświatowe (od 1 września 2017 r. do 31 sierpnia 2019 r.) oraz ustalenie sieci szkół ponadpodstawowych i specjalnych od 1 września 2019 r.

Przeprowadzone rozważania pozwalają zgodzić się z argumentacją A. Błasia:

Samorząd terytorialny, jako podmiot prawa odrębny od innych podmiotów, winien w pierwszym rzędzie swe prawa podmiotowe chronić przed naruszeniami ze strony innych podmiotów, ale i samemu praw tych nie naruszać, nie rozszerzać ich ani nie zawężać, nie instrumentalizować, nie manipulować nimi. [...] winien swymi działaniami umacniać państwo, wspierać rząd w jego polityce prowadzonej dla dobra wspólnego. [...] winien dystansować się od niekonstytucyjnej polityki rządu, własną polityką zaś nie powinien narażać na szwank interesu państwa. [...] Organy samorządu terytorialnego nie powinny własnymi działaniami podważać zaufania mieszkańców wspólnoty samorządowej ${ }^{82}$.

Podkreślmy — także w polityce oświatowej samorządowej w zakresie wykonywania zadań oświatowych.

78 „Rada gminy podejmuje uchwałę w sprawie projektu dostosowania sieci szkół podstawowych i gimnazjów do nowego ustroju szkolnego, wprowadzonego ustawą - Prawo oświatowe".

79 „Struktura organizacyjna szkoły podstawowej obejmuje klasy I-VIII, a w przypadku szkoły podstawowej dla dorosłych — klasy VII i VIII".

80 Zob. Zasady opiniowania przez Dolnośląskiego Kuratora Oświaty planów sieci publicznych szkół i przedszkoli z dnia 11 stycznia 2017 r., https://www.kuratorium.wroclaw.pl/wp-content/ uploads/2017/01/pismo-dko.pdf (dostęp: 31.01.2017).

81 Art. 213 ust. 1 u.p.w.p.o.: „Rada powiatu podejmuje uchwałę w sprawie projektu dostosowania sieci szkół ponadgimnazjalnych i specjalnych do nowego ustroju szkolnego, wprowadzonego ustawą - Prawo oświatowe oraz ustalenia sieci szkół ponadpodstawowych i specjalnych".

82 Studia nad samorzadem..., s. 9. 


\section{WPŁYW POLITYKI ADMINISTRACYJNEJ NA REFORMĘ EDUKACJI}

Edukacja publiczna zmienia się w obliczu wprowadzanych reform edukacyjnych, co ma związek m.in. ze współczesnymi uwarunkowaniami, jakie zachodzą w świecie, w państwie i jego administracji publicznej, np. cywilizacyjnymi, informacyjnymi, technologicznymi, reformami ustrojowo-systemowymi, przemianami gospodarczymi czy społeczno-demograficznymi, sprawiającymi, że rozwiązania, które były proponowane dotychczas, nie przystają do zmieniających się potrzeb przedkładanych na zadania publiczne. Tworzenie polityki edukacyjnej jest procesem ciągłym. Trzeba mieć na uwadze zależności, jakie zachodzą między polityką edukacyjną a polityką społeczną ${ }^{83}$. Podkreślmy w tym miejscu, że polityka społeczna oznacza

celowe oddziaływanie państwa, związków zawodowych i innych organizacji na istniejący układ stosunków społecznych, na kształtowanie warunków życia ludności oraz stosunków międzyludzkich. [...] ma zmierzać do poprawy warunków bytu i pracy szerokich warstw ludności, usuwania nierówności społecznych oraz podnoszenia kultury życia. [...] Zakres polityki społecznej obejmuje bowiem przede wszystkim podstawowe potrzeby społeczne, a więc wartości uznawane przez społeczeństwo za istotne do zaspokojenia w celu zapewnienia godnego życia ${ }^{84}$.

Cele i efekty reformy edukacji w Polsce po 1999 roku, jak i tych, które mają być wprowadzone w życie po 1 września 2017 r., wymuszają na politykach-decydentach odpowiednie zmiany w systemie oświatowym, powodując, że jako reforma społeczna ma ona swoich zwolenników i przeciwników. Mając na uwadze usprawnienie systemu edukacji po 1999 roku, D. Magierek pisze: „Konieczność zmian w sferze edukacji, oczywista dla wszystkich, nie rozwiązywała jednak podstawowych dylematów pojawiających się przy każdej reformie społeczno-gospodarczej: jak głębokie i jak szybko wprowadzone mają być konieczne zmiany"85, co oznacza, że przemianom tym nie może towarzyszyć pośpiech i determinacja rządu do ich wprowadzenia czy poczucie niepewności oraz sceptycyzm i opór środowisk edukacyjnych nie do końca przekonanych o konieczności gruntownych przeobrażeń edukacyjnych, tj. przekształcania szkół, dostosowania sieci szkół do zmiany struktury szkolnej. Ze strony zainteresowanych środowisk wskazano wtedy, tak jak dzisiaj, na wiele kwestii wdrażanej reformy edukacji, np.: ,[...] brakuje rzetelnej podstawy merytorycznej, przepisów wykonawczych, jasno określonych mechanizmów finansowania, czasu, który pozwoliłby ją wdrożyć w sposób przemyślany, zaplanowany i niegenerujący błędów" 86 czy wyrażony wobec reformy oświaty sprzeciw wobec zmian w argumentacji: „monopol państwa w sprawach edukacji, brak dialogu i dyskusji ze środowiskiem edukacyjnym w zakresie pla-

83 Zob. D. Magierek, Polityka edukacyjna a polityka społeczna, [w:] Wprowadzenie do polityki społecznej, red. R. Gabryszak, D. Magierek, Warszawa 2009, s. 181-201.

${ }^{84}$ M. Polak, Zasady i instrumenty polityki spotecznej, [w:] Wprowadzenie do polityki..., s. 32.

85 D. Magierek, op. cit., s. 181.

86 A. Satel, Punkty sporne reformy, „Dyrektor Szkoły” 2016, nr 12, s. 10. 
nowanych zmian, ideologizacja nauczania oraz wychowania dzieci i młodzieży, a także ogromne koszty [... "’87. Brak poczucia akceptacji dokonujących się przemian w edukacji publicznej i niepokój płynący ze środowisk nie tylko edukacyjnych wzbudzać może niewyjaśniona kwestia wdrożenia reformy i sposobów jej finansowania, niepotrzebny pośpiech, niejednoznacznie przekonanie do nieustannego poprawiania edukacji, wynikający m.in. $z$ braku podstaw merytorycznych, badawczych, jakie legły u podstaw wprowadzanych zmian przez MEN, państwowy monopol, niekompatybilny polski system oświaty z innymi systemami, np. w Europie, wątpliwości rodziców co do zmian w szkolnictwie i wyboru ścieżki edukacyjnej dla swoich dzieci czy traktowanie spraw edukacji jako narzędzia politycznego rządu ${ }^{88}$.

Reformy powinny być przemyślane i uzasadnione potrzebą wprowadzonych zmian edukacyjnych, oparte na faktach i ocenie następstw proponowanych rozwiązań systemowych, a nie wyobrażeniach o edukacji ${ }^{89}$. Ale też aktualne jest pytanie, czy wcześniejsze reformy edukacji były akceptowane społecznie? A może obecne przeobrażenia są odpowiedzią na to, co nie działało dobrze wcześniej i należy to zmienić? Edukacja jest tym wyzwaniem rozwoju społecznego, w którym

każda zmiana systemowa [...] wymaga rzeczowego uzasadnienia opartego na badaniach naukowych i szczegółowych analizach. [...] brak jest głębszej analizy stanu polskiej edukacji, a tym samym merytorycznego uzasadnienia dla wdrażanych zmian [...]. Związek Nauczycielstwa Polskiego inicjuje obywatelski ruch na rzecz przeprowadzenia referendum z inicjatywy obywateli w sprawie reformy systemu oświaty ${ }^{90}$.

Przedłożona została deklaracja w zakresie inicjatywy przeprowadzenia ogólnokrajowego referendum w sprawie reformy edukacji pod hasłem „Referendum szkolne”. Pytanie: „Czy jest Pani/Pan przeciw reformie edukacji, którą rząd wprowadza od 1 września 2017 roku?" znajduje się w deklarowanym jako obywatelski wniosek o ogólnopolskie referendum w tej sprawie ${ }^{91}$. Jednak to przyszłość pokaże, czy tak sformułowane pytanie znajdzie akceptację obywatelską i czy referendum ogólnokrajowe w sprawie edukacji dojdzie do skutku, zwłaszcza że nie jest to pierwsze zgłaszane referendum w systemie oświaty. Widoczne jest, że reforma edukacji rozłożona jest $\mathrm{w}$ czasie, etapami wprowadzane są rozwiązania prawne w prawie oświatowym, które mogą wzbudzać wątpliwości interpretacyjne w kwestiach organizacyjnych, podstaw programowych czy innych. Z pewnością problemy ze stosowaniem instrumentów polityki społecznej, w tym prawnych,

87 A. Jakubiec, Sprzeciw wobec zmian, „Dyrektor Szkoły” 2016, nr 12, s. 13.

88 Zob. A. Satel, op. cit., s. 10-12; A. Jakubiec, op. cit., s. 13-15.

89 Zob. W. Kaleta, Samorząy szykuja się do reformy, „Dyrektor Szkoły” 2016, nr 12, s. 18-21; A. Jeżowski, Wymuszone pożegnanie, „Dyrektor Szkoły” 2016, nr 12, s. 16-18.

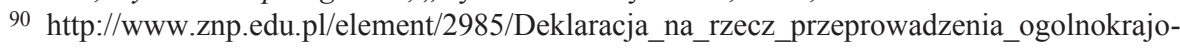
wego_referendum (dostęp: 31.01.2017).

${ }^{91}$ http://www.znp.edu.pl/element/2991/REFERENDUM_SZKOLNE (dostęp: 7.02.2017); http://www.referendum-szkolne.pl/ (dostęp: 7.02.2017). 
będą ujawniały się na bieżąco. To, co jest niepodważalne, to, że szkoła i nauczyciel muszą się zmieniać. Zmieniają się potrzeby edukacyjne w społeczeństwie, zachodzą zmiany w otoczeniu szkoły, problemy wyzwala też sam proces nauczania i wychowania. Nie należy też zapominać o kosztach dotychczasowych reform edukacyjnych, a także kwestii społecznego zmęczenia obywateli „eksperymentowaniem" w szkolnictwie przez reformę edukacji. Pojawiająca się kolejna reforma edukacji jest zawsze wyzwaniem dla poprzedniej, która też nie była jednoznacznie przyjmowana i oceniana przez społeczeństwo (np. nieprzewidywalność polityki edukacyjnej państwa i j.s.t., niestałość zadań oświatowych j.s.t., decentralizacja oświaty a rozwiązania rynkowe, np. zarządzanie marketingowe szkołą, marketing szkoły, ekonomika oświaty, niedofinansowanie edukacji, zmiany obniżenia obowiązku szkolnego).

Polski system oświaty podlega bezustannym zmianom dokonującym się wewnątrz i na zewnątrz szkoły, w jej przestrzeni edukacyjnej, na tle zachodzących w państwie przemian i oczekiwań społecznych zmieniającej się rzeczywistości oświatowej, w której musi się odnaleźć ${ }^{22}$. Dodajmy, że edukacja staje w obliczu złożoności wyzwań płynących z procesów globalizacji świata, zmiany rynku usług edukacyjnych, zmiany rynku pracy, staje wobec wielości zachodzących zjawisk społecznych, różnorodności podmiotów edukacyjnych prowadzących szkoły publiczne i niepubliczne oraz sposobów realizacji zadań publicznych $\mathrm{w}$ dziedzinie oświaty itd., działając w warunkach nieprzewidywalnych determinantów systemowych, przemian ustrojowych, instytucjonalnych i organizacyjnych, uwzględniając aktualnie uwarunkowania polityki edukacyjnej i społecznej w państwie.

\section{ADMINISTRATIVE AND EDUCATIONAL POLICY OF LOCAL SELF-GOVERNMENT ON THE BASIS OF ADMINISTRATIVE AND LEGAL SCIENCES}

\section{Summary}

Present-day factors of public administration, variability of educational law, uncertainty of state educational policy in the scope of educational reform, its political instrumentalization. These are exemplary factors of changes which have impact on educational policy of local self-government and ways of realization public tasks.

Local education as the sphere of public administration activity has changed rapidly in recent years and often shows differences between expectations and fulfillment of social needs in the scope of education.

92 R. Raszewska-Skałecka, Przemiany i wyzwania współczesnej przestrzeni edukacji, [w:] Współczesna przestrzeń edukacyjna. Geneza, przemiany, nowe znaczenia, red. E. Musiał, M. Bednarska, Kraków 2013, s. 59-77. 